\title{
Improved strategy of an MPPT based on the sliding mode control for a PV system
}

\author{
Taouni Abderrahim ${ }^{1}$, Touati Abdelwahed ${ }^{2}$, Majdoul Radouane ${ }^{3}$ \\ ${ }^{1}$ Laboratory of Electrical Systems and Control Engineering, faculty of sciences Aïn Chock, \\ Hassan II University, Morocco \\ ${ }^{2,3}$ Laboratory of Structural Engineering, Intelligent Systems and Electrical Energy ENSAM, \\ Hassan II University, Morocco
}

\begin{tabular}{l} 
Article Info \\
\hline Article history: \\
Received May 9, 2019 \\
Revised Dec 12, 2019 \\
Accepted Jan 8, 2020 \\
\hline
\end{tabular}

Keywords:

Buck converter Incremental conductance Perturb and observe algorithm PV module

Sliding mode, MPPT

\begin{abstract}
The energy produced using a photovoltaic (PV) is mainly dependent on weather factors such as temperature and solar radiation. Given the high cost and low yield of a PV system, it must operate at maximum power point (MPP), which varies according to changes in load and weather conditions. This contribution presents an improved maximum power point tracking (MPPT) controllers of a PV system in various climatic conditions. The first is a sliding mode MPPT that designed to be applied to a buck converter in order to achieve an optimal PV array output voltage. The second MPPT is based on the incremental conductance algorithm or Perturb-and-Observe algorithm. It provides the output reference PV voltage to the sliding mode controller acting on the duty cycle of the DC-DC converter. Simulation is carried out in SimPower toolbox of Matlab/Simulink. Simulation results confirm the effectiveness of the sliding mode control MPPT under the parameter variation environments and shown that the controllers meet its objectives.
\end{abstract}

Copyright (C) 2020 Institute of Advanced Engineering and Science. All rights reserved.

\section{Corresponding Author:}

Taouni Abderrahim,

Laboratory of Electrical Systems and Control Engineering,

Hassan II University,

Mohammadia School of Engineers, Rabat, Morocco,

Email: taouni40@hotmail.com

\section{INTRODUCTION}

Photovoltaic systems use solar cells or a group of them to convert sunlight directly into electricity. The power produced by photovoltaic systems depends on the irradiation and temperature of the solar cells [1]. Habitually, the energy produced by solar cells is used to provide power to a load and the remaining energy is stored in batteries. The nonlinear current voltage (I-V) characteristic of PV presents a major challenge in their usage, which leads to a single maximum power point MPP in the power voltage (P-V) curve $[2,3]$. This point varies with temperature and solar radiation that makes it harder to achieve.

The major principle of MPPT is to extract the maximum available power from PV module by making them operate at the most efficient voltage (maximum power point) [4-6]. Moreover, the maximum power varies according to the level of solar radiation, the ambient temperature and the temperature of the photovoltaic cells [7]. The MPPT functions as an integrated system, including a combination of a hardware part constituted by a DC-DC converter, and the control algorithm acting as a software part of the MPPT. This combination determines the value of the PV system [8].

Indeed, the role of the MPPT is tuning the operating point of the PV system, so as to extract the maximum power provided by the PV system. The design of an efficient MPPT scheme must ensure accurate and robust tracking, overcoming the presence of modeling errors, the non-linearity of the currentvoltage characteristic curves of the photovoltaic cell and the rapid changes in temperature and solar 
insolation. To reach the MPP, many papers have been presented with different control schemes which can extract maximum of solar power as much as possible. So, several methods have been implemented, namely tracking systems Perturb and Observe (P\&O) [9-11], incremental conductance [12], open circuit voltage, and short circuit current [13]. In order to enhance their performance and to minimize the material, modified techniques have been proposed.

The P\&O method is extensively used due to its simple implementation. It consists in the perturbation of the panel voltage periodically; by the variation (increasing and decreasing) of the cyclical ratio of the converter to reach MPPT. In incremental conductance, the voltage and current of the solar panel are measured to augur the effect of the variation of the voltage on the output power. The MPPT algorithms above can be implemented with a convergent stability guaranteed. However, in both methods rapid convergence requires a large step of perturbation resulting more chattering around MPP. In addition, the output power change reflects not only the effect of the variation of the voltage perturbed because the power can be changed by changing meteorological conditions [14].

Others MPPT control systems based on fuzzy logic have been introduced [15-18]. The fuzzy logic controllers (FLCs) are successfully applied in the implementation of MPPT. They offer better performance. Their control is robust and does not require exact prior knowledge of the mathematical model of the system. Fuzzy-based MPPT algorithms surpass those using P \& O and incremental conductance because of their robustness [19]. An artificial neural network (ANN) has also been used with the FLC for the MPPT of the PV module [20, 21]. The Fuzzy and ANN-based MPPT algorithms exceed all others because of their robust response. However, the cost of calculation, the complexity of the implementation and the tendency to converge towards the local maxima in case of partial shading are the disadvantages.

Lately, many researches are underway in the field of non-linear control. Many non-linear controllers are also used to track PV module MPPs, including the sliding mode and backstepping control [22-27]. A Photovoltaic cell is a non-linear. Similarly, the converters are also modeled assuming that they respond linearly to the variable duty cycle. However, they also describe nonlinear behavior. The robustness and stability that a nonlinear controller can realize when tracking the MPP cannot be obtained by the others controllers [29]. In this paper, the sliding mode control (SMC) is proposed to regulate the duty cycle of DC-DC buck converter to bring the PV module to operate at its maximum power point. This control strategy present attractive features, such good stability, simplicity, high accuracy, robustness and a finite response time [29-31]. Two MPPTs versions are developed, the first is a Sliding Mode Controller MPPT that brings the solar panel to work maximum power point Figure 1. Secondly, an MPPT algorithm P\&O or incremental conductance, provides to a sliding mode controller the output reference PV voltage. This controller acts on the switch of the buck converter for the solar panel output voltage rejoins the reference voltage Figure 2.

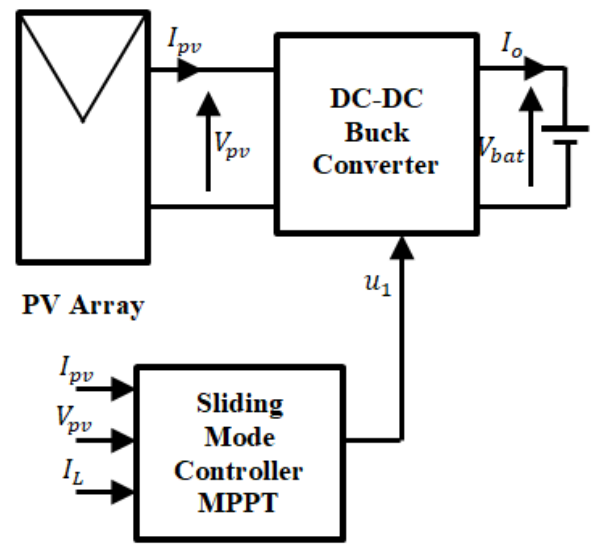

Figure 1. Control scheme with sliding mode controller MPPT

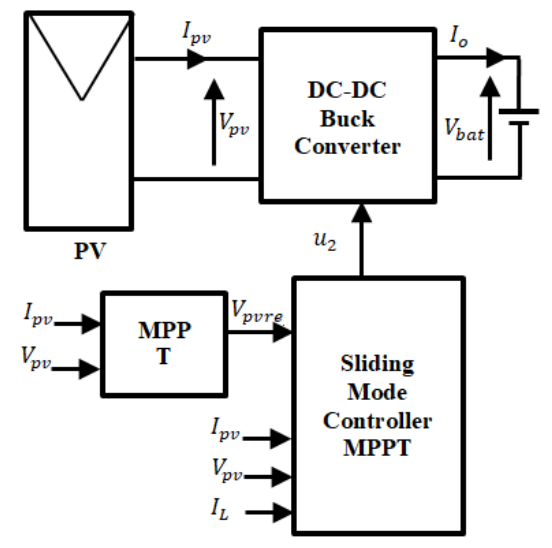

Figure 2. Control scheme with sliding mode controller and MPPT algorithm

\section{SYSTEM MODELING}

\subsection{PV characteristic}

A solar cell is a basic component of a PV system. Generally, only a few watts (2W) of power are produced by each solar cell and corresponds to the open circuit voltage is in between 0.5 and $0.7 \mathrm{~V}$ depending upon the material of solar cell. Since this power is insufficient to supply most devices, the voltage must be increased and therefore increasing the power. PV array module consists of number of series and

Improved strategy of an MPPT based on the sliding mode control for a PV system (Taouni Abderrahim) 
parallel connected cells as per the required rating of PV array [33]. So, to increase the voltage these cells are clustered in series and in parallel to increase the current. Solar cells present naturally nonlinear characteristics $\mathrm{I}-\mathrm{V}$ and $\mathrm{P}-\mathrm{V}$, which depend on the solar radiation and the temperature of the cell. A simple electrical equivalent model with single diode is adopted. As shown in Figure 3, the equivalent circuit of a PV cell has a current source (Ipv), a diode connected in parallel, a series resistor $(R s)$ and a parallel resistor $(R p)$ [34]. The equation which reflects the relation between the voltage and current in the PV module can be written as:

$$
I_{p v}=I_{p h}-I_{0} \cdot\left(\exp \left(\frac{V_{p v}+I_{p v} R_{S}}{a \cdot V_{T}}\right)-1\right)-\frac{V_{p v}+I_{p v} R_{S}}{R_{p}}
$$

where $\boldsymbol{I}_{p h}$ is the current generated by the incidence of light. Io is the reverse saturation current, $\boldsymbol{V}_{T}$ is the junction thermal voltage $\left(V_{T}=\boldsymbol{N}_{s} . \boldsymbol{k} \boldsymbol{T} / \boldsymbol{q}\right)$ of $\boldsymbol{N}_{S}$ series-connected solar cells per module, q is the electron charge $\left(1.60217646 \times 10^{-19} \mathrm{C}\right), \mathrm{k}$ is the Boltzmann constant $\left(1.3806503 \times 10^{-23} \mathrm{~J} / \mathrm{K}\right), \mathrm{T}$ is the temperature of the p-n junction in Kelvin and a is the diode ideality factor. The light generated current $\boldsymbol{I}_{\boldsymbol{p} h}$ and the saturation current depend on the temperature and solar radiation that can be expressed by the following equation:

$$
I_{p h}=\left(I_{p h, n}+k_{i}\left(T-T_{n}\right)\right) \cdot \frac{G}{G_{n}}
$$

where $\boldsymbol{I}_{\boldsymbol{p h}, \boldsymbol{n}}$ is the light generated current at the nominal condition, $\boldsymbol{G}_{\boldsymbol{n}}$ is the irradiance at STC, G is the surface irradiance of the cell and $\boldsymbol{k}_{\boldsymbol{i}}$ is the short circuit current coefficient.

$$
I_{0}=I_{0, n} \cdot\left(\frac{T_{n}}{T}\right)^{3} \cdot \exp \left[\frac{q E_{g}}{a k}\left(\frac{1}{T_{n}}-\frac{1}{T}\right)\right]
$$

where $\boldsymbol{E}_{\boldsymbol{g}}$ is the band gap energy of the semiconductor (1.12eV for the silicon), $\boldsymbol{I}_{\boldsymbol{o}, \boldsymbol{n}}$ and $\boldsymbol{V}_{\boldsymbol{o c}, \boldsymbol{n}}$ represents respectively the nominal saturation current and the open circuit voltage at STC, also $\boldsymbol{T}_{\boldsymbol{n}}$ and $\boldsymbol{T}$ are, respectively, the nominal and the actual temperatures in Kelvin.

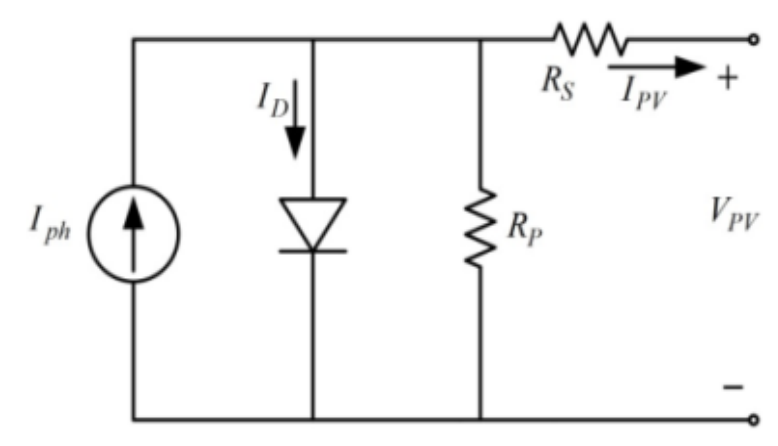

Figure 3. Equivalent circuit of solar cell

The PV array considered in this work is the monocristalin 100W Sunpower Flexible solar panel. The corresponding electrical characteristics are listed in Table 1. In order to use the solar panel in the following simulations; the identification of single diode model parameters is performed. The method adopted to determine $\boldsymbol{I}_{\boldsymbol{p h}}, \boldsymbol{I}_{\boldsymbol{o}}$, has $\boldsymbol{R}_{\boldsymbol{S}}$ and $\boldsymbol{R}_{\boldsymbol{P}}$ is the detailed in [35]. It is a simple and accurate method that allows using data supplied by the manufacturer to calculate these parameters. The results obtained are shown in Table 2. Figure 4 and Figure 5 show the I-V curves and P-V related to solar panel used for different Temperature Levels and different irradiance levels. The P-V curves pass through maximums in which the PV generates more power than other points. There are maximum power points for each curve. Therefore, during one day the maximum power point of a PV varies according to the irradiance and temperature. 
Table1. Solar array datasheet parameters

$\begin{array}{cc}\text { Imp } & 5.7 \mathrm{~A} \\ \text { Vmp } & 17.7 \mathrm{~V} \\ \text { Pmp } & 100.89 \mathrm{~W} \\ \text { Isc } & 6.1 \mathrm{~A} \\ \text { Voc } & 21.7 \mathrm{~V} \\ \mathrm{Ns} & 32 \\ \mathrm{Ki} & 0.015 \% /{ }^{\circ} \mathrm{C} \\ \mathrm{Kv} & -0.34 \% /{ }^{\circ} \mathrm{C}\end{array}$

Table 2. Parameters obtained of the solar panel

\begin{tabular}{cc}
\hline Solar panel parameter & Value \\
\hline $\mathrm{a}$ & 1.3 \\
$\mathrm{R}_{\mathrm{S}}(\Omega)$ & 0.16272629 \\
$\mathrm{R}_{\mathrm{P}}(\Omega)$ & 299.42 \\
$\mathrm{I}_{\mathrm{O}}(\mathrm{A})$ & $9.3429 \mathrm{e}-9$ \\
$\mathrm{Iph}(\mathrm{A})$ & 6.10331 \\
\hline
\end{tabular}

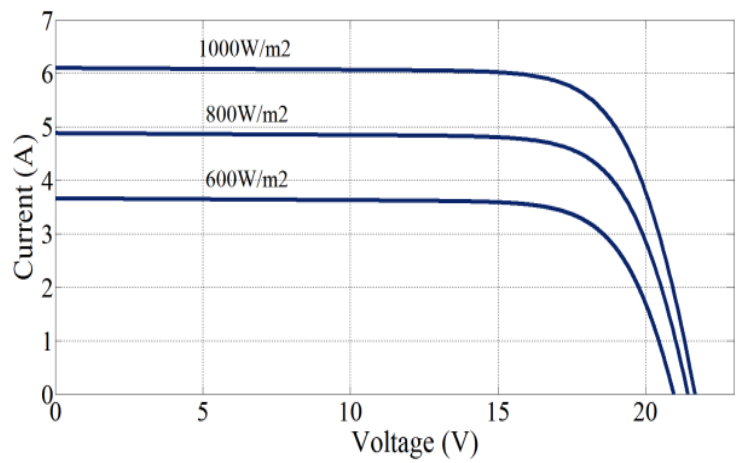

(a)

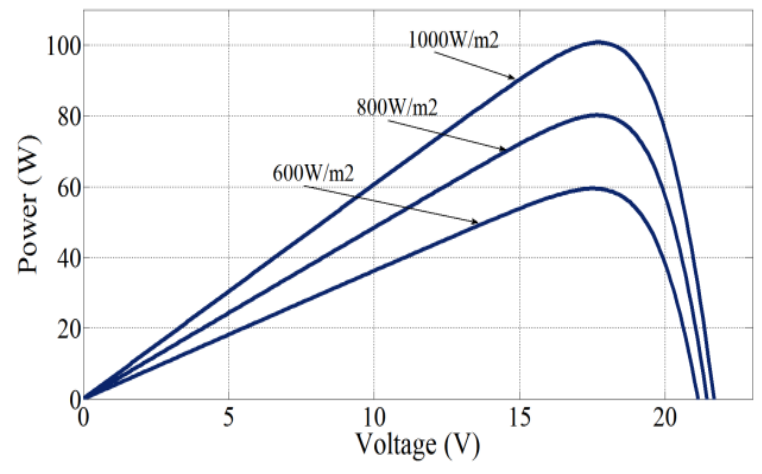

(b)

Figure 4. (a) Current-voltage and (b) Power-voltage curves of PV array at $25^{\circ} \mathrm{C}$

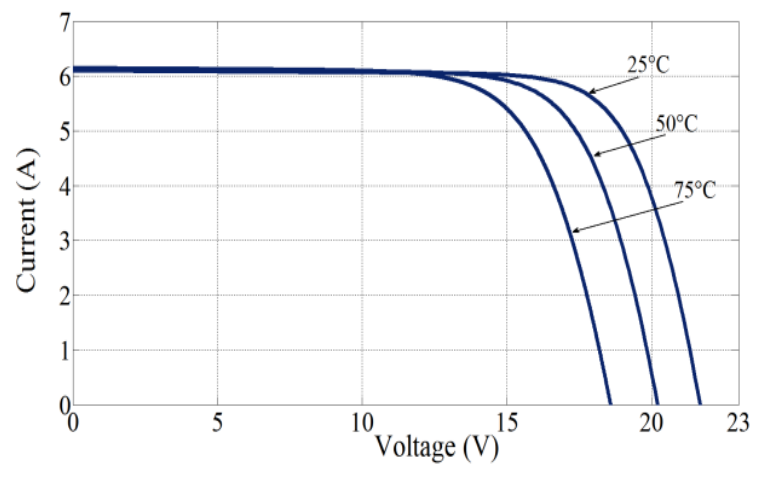

(a)

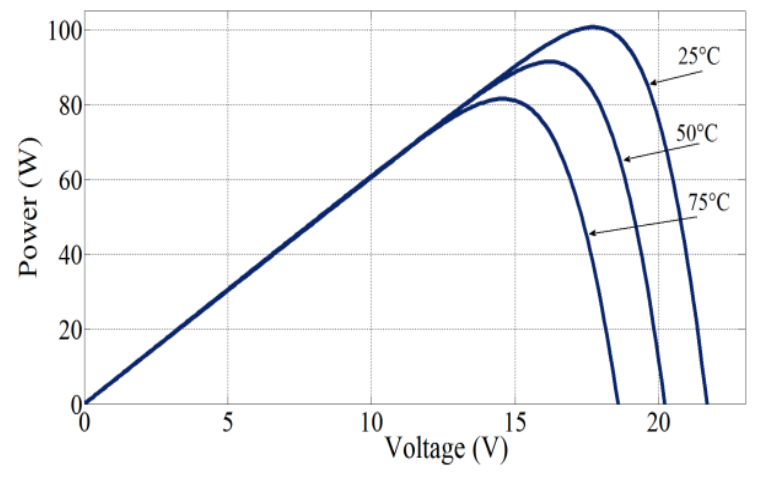

(b)

Figure 5. (a) Current-voltage and (b) Power-voltage curves of PV array at $1000 \mathrm{~W} / \mathrm{m}^{2}$

\subsection{Buck converter modeling}

The averaged model of the buck converter is obtained by applying the fundamental laws governing the functioning of the system. The converter scheme is shown in Figure 6. The dynamic equations of this converter can be expressed as: 


$$
\left\{\begin{array}{c}
\frac{d x_{1}}{d t}=\frac{u}{L} x_{2}-\frac{V_{b a t}}{L} \\
\frac{d x_{2}}{d t}=\frac{1}{R_{p v} C_{1}} x_{2}-\frac{u}{C_{1}} x_{1}
\end{array}\right.
$$

where $x=\left[\begin{array}{ll}x_{1} & x_{2}\end{array}\right]^{T}=\left[\begin{array}{ll}I_{L} & V_{p v}\end{array}\right]^{T}, R_{p v}=\frac{V_{p v}}{I_{p v}}$ as an equivalent load connected to PV panel and $u$ is duty cycle. The buck converter is powered by the solar panel. The input voltage varies continuously with the weather. Therefore, the duty cycle should change to follow the maximum power point of the photovoltaic array.

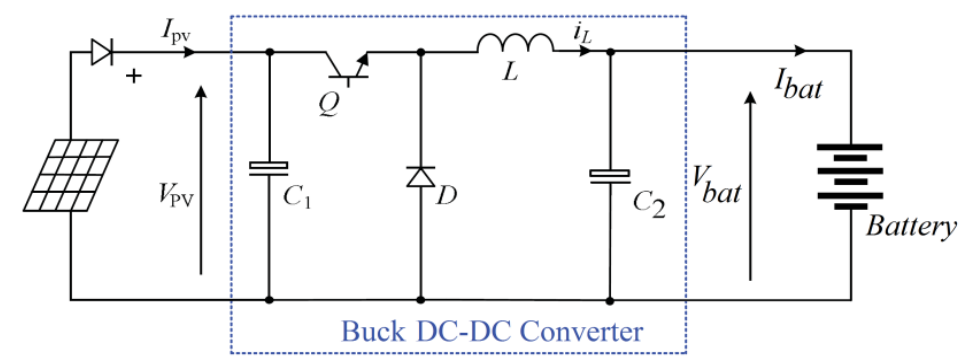

Figure 6. Scheme of the DC-DC buck converter

\section{SLIDING MODE CONTROL DESIGN:}

Equation (4) can be written as follow:

$$
\dot{x}=f(x)+g(x) d+H
$$

where $f(\mathrm{x})=\left(\begin{array}{c}0 \\ \frac{\mathrm{x}_{2}}{\mathrm{R}_{\mathrm{pv}} C_{1}}\end{array}\right), \mathrm{g}(\mathrm{x})=\left(\begin{array}{c}\frac{\mathrm{x}_{2}}{\mathrm{~L}} \\ \frac{-\mathrm{x}_{1}}{\mathrm{C}_{1}}\end{array}\right)$ and $H=\left(\begin{array}{c}-\frac{V_{b a t}}{L} \\ 0\end{array}\right)$

According to the PV curves shown for various radiation levels in Figure 4 (b), the maximum power point MPP expression is characterized by:

$$
\frac{\partial \mathrm{P}_{\mathrm{pv}}}{\partial \mathrm{V}_{\mathrm{pv}}}=\frac{\partial\left(\mathrm{V}_{\mathrm{pv}} \mathrm{I}_{\mathrm{pv}}\right)}{\partial \mathrm{V}_{\mathrm{pv}}}=\frac{\partial \mathrm{I}_{\mathrm{pv}}}{\partial \mathrm{V}_{\mathrm{pv}}} \mathrm{V}_{\mathrm{pv}}+\mathrm{I}_{\mathrm{pv}}=0
$$

This expression is chosen as the sliding surface for the SMC MPPT

$$
\mathrm{S}(\mathrm{x})=\frac{\partial \mathrm{P}_{\mathrm{pv}}}{\partial \mathrm{V}_{\mathrm{pv}}}
$$

Analyzing the relationship between the state of $\mathrm{S}(\mathrm{x})$ and the position of the operating point on Figure (7), it is necessary to make the choice of the following control law:

$$
u=\left\{\begin{array}{l}
0 \text { if } S(x) \geq 0 \\
1 \text { if } S(x)<0
\end{array}\right.
$$

The equation of the photovoltaic current is given in (1). When we neglect the effect of the resistances RS and RP, the current Ipv becomes:

$$
I p v=I p h-I_{o}\left(\exp \left(\frac{V_{p v}}{a V_{T}}\right)-1\right)
$$


So, $\mathrm{S}(\mathrm{x})$ can be written as:

$$
S(x)=\frac{\partial I_{p v}}{\partial V_{p v}} V_{p v}+I_{p v}=I_{p h}-I_{o}\left(1+\frac{V_{p v}}{a V_{T}}\right) \exp \left(\frac{V_{p v}}{a V_{T}}\right)+I_{o}
$$

The equivalent control input $\mathrm{u}_{\mathrm{eq}}$ is obtained from the condition:

$$
\begin{aligned}
& \dot{S}(x)=0 \text { and } \dot{S}(x)=\frac{d S(x)}{d t}=-\left(\frac{V_{p v}}{a V_{T}}+2\right) \frac{I_{o}}{a V_{T}} \exp \left(\frac{V_{p v}}{a V_{T}}\right) \dot{V}_{p v}=0 \\
& \Rightarrow \dot{V}_{p v}=0
\end{aligned}
$$

$u_{e q}$ is then deducted from (4):

$$
u_{e q 1}=\frac{x_{2}}{R_{p v} x_{1}}=\frac{I_{p v}}{I_{L}} \text { with } I_{L} \neq 0
$$

The equivalent command is effective once the trajectory of the system state reaches the sliding surface (sliding mode). A reaching law must be expressed to bring the trajectory to the sliding surface during the convergence mode.

The simplest form that can take is as follows:

$$
u_{n}=-k_{1} \cdot \operatorname{sign}(S(x))
$$

where $\mathrm{k}_{1}$ represent a positive constant of the synthesis discontinuous law. The sliding mode control law can be written as below:

$$
u_{1}=u_{e q 1}+u_{n}
$$

To verify convergence in finite time, a candidate Lyapunov function is defined by:

$$
V(x)=\frac{1}{2} S^{2}(x)
$$

Its dynamic, relative to time, is given by:

$$
\dot{V}(x)=S(x) \dot{S}(x)<0
$$

To ensure convergence in a finite time, we can choise :

$$
\dot{S}(x)=-\left(\frac{V_{p v}}{a V_{T}}+2\right) \frac{I_{o}}{a V_{T}} \exp \left(\frac{V_{p v}}{a V_{T}}\right) \frac{d V_{p v}}{d t}
$$

In case: $\quad \mathrm{S}(\mathrm{x})>0$

Whence $\quad \mathrm{S}(\mathrm{x}) \dot{\mathrm{S}}(\mathrm{x})<0$

In case: $\quad \mathrm{S}(\mathrm{x})<0$ and $\frac{d V_{p v}}{d t}<0 \Rightarrow \dot{S}(x)>0$

Whence $\quad \mathrm{S}(\mathrm{x}) \dot{\mathrm{S}}(\mathrm{x})<0$

It is demonstrated that the system is asymptotically stable.

\section{SLIDING MODE CONTROLLER WITH MPPT ALGORITHM}

In this section, the design of a sliding mode controller (SMC) using a reference voltage provided by an MPPT algorithm will be presented. For this control, the sliding surface becomes:

$$
S(x)=x_{2}-V_{\text {pvref }}
$$


where $\mathrm{V}_{\text {pvref }}$ is voltage provided by an MPPT algorithm (Perturb \& Observe or Incremental conductance). The control law for this case is described by:

$$
\begin{cases}0 & \text { if } S(x)<0 \\ 1 & \text { if } S(x)>0\end{cases}
$$

The equivalent control input $\mathrm{u}_{\mathrm{eq} 2}$ is obtained from the condition:

$$
\begin{aligned}
& \dot{S}(x)=0 \\
& \dot{S}(x)=\dot{x}_{2}-\dot{V}_{\text {pvref }}=0 \\
& \dot{S}(x)=\frac{1}{R_{p v} C_{1}} x_{2}-\frac{u_{e q 2}}{C_{1}} x_{1}-\dot{V}_{p v r e f}=0 \\
& \Rightarrow u_{e q 2}=\frac{x_{2}}{R_{p v} x_{1}}-\frac{C_{1}}{x_{1}} \dot{V}_{p v r e f} \\
& u_{e q 2}=\frac{I_{p v}}{I_{L}}-\frac{C_{1}}{I_{L}} \dot{V}_{p v r e f} \quad \text { with } I_{L} \neq 0
\end{aligned}
$$

a reaching law is taken:

$$
u_{n}=k_{2} \cdot \operatorname{sign}(S(x))
$$

where $\mathrm{k}_{2}$ is a positive constant. The sliding mode control law can be written as below:

$$
u_{2}=u_{e q 2}+u_{n}
$$

\subsection{Maximum power reference voltage}

The role of the MPPT algorithm is to calculate the optimal output voltage of the photovoltaic panel called Vpvref which allows the PV system to function at its MPP. For that two well-known algorithms perturb-and-Observe algorithm with adaptive step and Incremental Conductance algorithm are tested.

\subsubsection{Adaptive $\mathrm{P} \& O$ algorithm}

The algorithm adopted for adaptive Perturb \& Observe is described as follows:

$$
\left\{\begin{array}{c}
V_{\text {pvref }}(t)=V_{\text {pvref }}(t-h)+k_{P \& O} \cdot \operatorname{sign}\left(\frac{\Delta P_{p v}}{\Delta V_{p v}}\right) \\
\Delta P_{p v}=P_{p v}(t)-P_{p v}(t-h) \\
\Delta V_{p v}=V_{p v}(t)-V_{p v}(t-h) \\
k_{P \& O}=k_{3} \cdot\left|\Delta P_{p v}\right|
\end{array}\right.
$$

where $\mathrm{k}_{\mathrm{P} \& \mathrm{O}}$ an adaptive step is dependent on the change of the PV power and $\mathrm{h}$ is the step time. The positive constant gain $\mathrm{k}_{3}$ is adjusted to obtain the best functioning of the MPPT.

\subsubsection{Incremental conductance algorithm}

The algorithm adopted for Incremental Conductance is described as follows:

$$
\left\{\begin{array}{c}
V_{\text {pvref }}(t)=V_{\text {pvref }}(t-h)+k_{\text {Inc }} \cdot \operatorname{sign}\left(\frac{\mathrm{I}_{p v}}{\mathrm{~V}_{p v}}+\frac{\Delta \mathrm{I}_{p v}}{\Delta \mathrm{V}_{p v}}\right) \\
\Delta I_{p v}=I_{p v}(t)-I_{p v}(t-h) \\
\Delta V_{p v}=V_{p v}(t)-V_{p v}(t-h) \\
k_{\text {Inc }}=k_{4} \cdot\left|\Delta I_{p v}\right|
\end{array}\right.
$$

where $\mathrm{k}_{\text {Inc }}$ an adaptive step is dependent on the change of the PV power and $\mathrm{h}$ is the step time. The positive constant gain $\mathrm{k}_{4}$ is adjusted to obtain the best suitable performances of the MPPT. 


\section{SIMULATION RESULTS}

To verify the validity and effectiveness of the proposed sliding mode controllers, simulations are drawn to illustrate their performance. The controlled system is a buck dc-dc converter with the components indicated in Table 3. The parameters of the designed controllers are chosen as reported in Table 4. In this study, the monocrystalline 100W Sunpower Flexible solar panel is selected as the source of photovoltaic energy. The number of solar panels chosen to provide $500 \mathrm{~W}$ maximum power is 5 modules connected in series. The simulation time is chosen short to show the response time of the studied controllers. Irradiance profile is shown in Figure 7 (f) and the Figures 7 (a-c) represent respectively the evolution of voltage, current and power of the PV array in response to the irradiance variation using sliding mode controller SMC MPPT. The voltage, current and power of the PV array using the SMC with Perturb and Observe MPPT algorithm are illustrated in Figures 8 (a-c) and those corresponding to the SMC with incremental conductance are in Figures 9 (a-c).

The load voltages corresponding to the different controllers are shown in Figure 7 (d), Figure 8 (d) and Figure 9 (d). The variations of duty cycle are depicted in Figure 7 (e), Figure 8 (e) and Figure. 9 (e). From simulations, the robustness of developed controllers is observed. The maximum power is achieved with excellent accuracy seen the variation of irradiance. From the various simulation results, we can conclude that the sliding-mode and the incremental-conductance control modes have faster convergence times to reach the smaller MPP power point compared to the perturbed and observed algorithm.

\begin{tabular}{cc} 
Table3.Parameters of the buck converter \\
\hline $\mathrm{C}_{1}$ & $660 \mu \mathrm{F}$ \\
$\mathrm{C}_{2}$ & $100 \mu \mathrm{F}$ \\
$\mathrm{L}$ & $120 \mu \mathrm{H}$ \\
$\mathrm{R}_{\mathrm{L}}$ & $1.8 \Omega$ \\
\hline
\end{tabular}
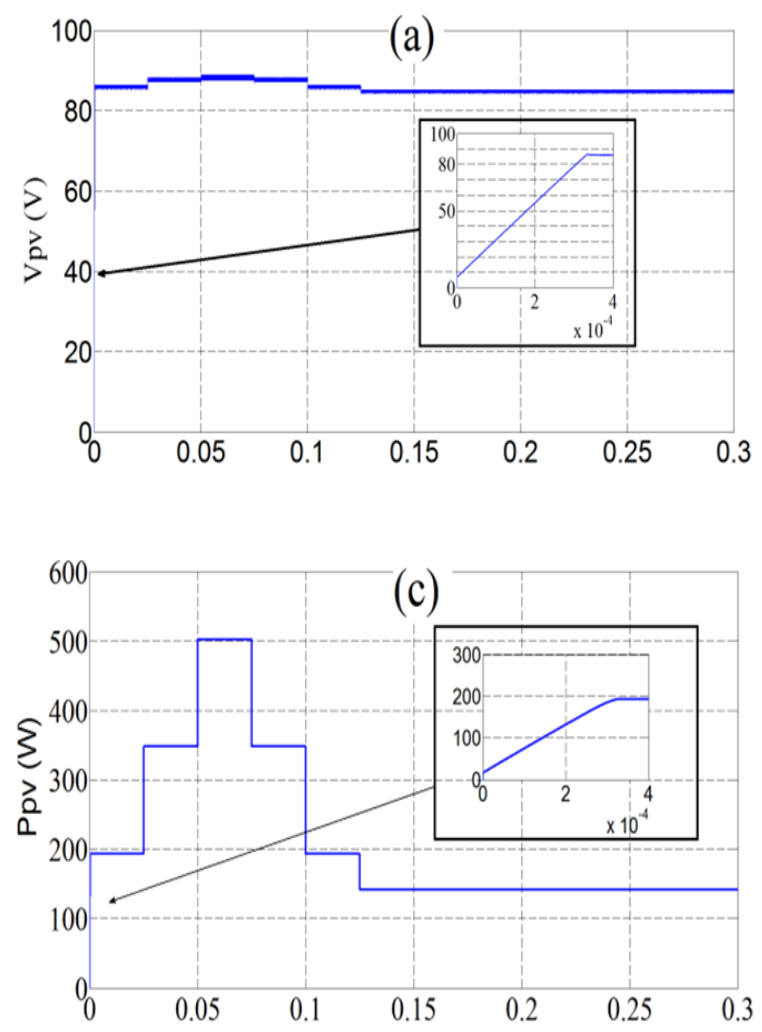

Table 4. controllers parameters

\begin{tabular}{cc}
\hline $\mathrm{k}_{1}$ & 10 \\
$\mathrm{k}_{2}$ & 1 \\
$\mathrm{k}_{3}$ & 0.001 \\
$\mathrm{k}_{4}$ & 4 \\
\hline
\end{tabular}
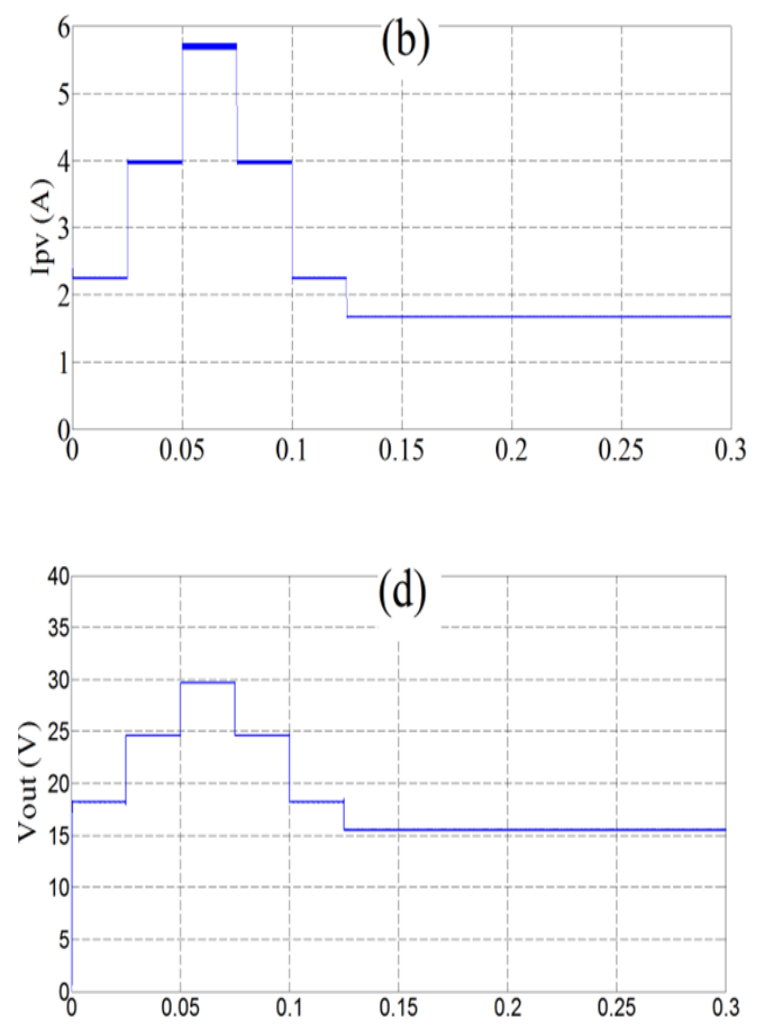

Figure 7. (a-c) Respectively voltage, current and power of PV array, (d) load voltage 

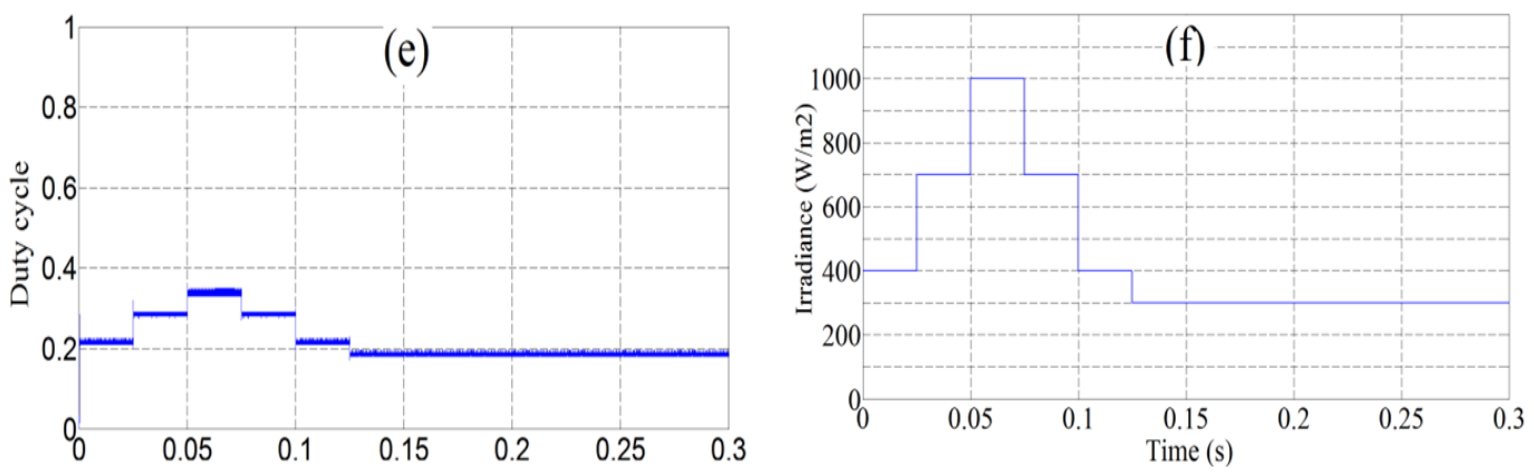

Figure 7. (e) Duty cycle of buck control and (f) irradiance profile using SMC MPPT (continue)
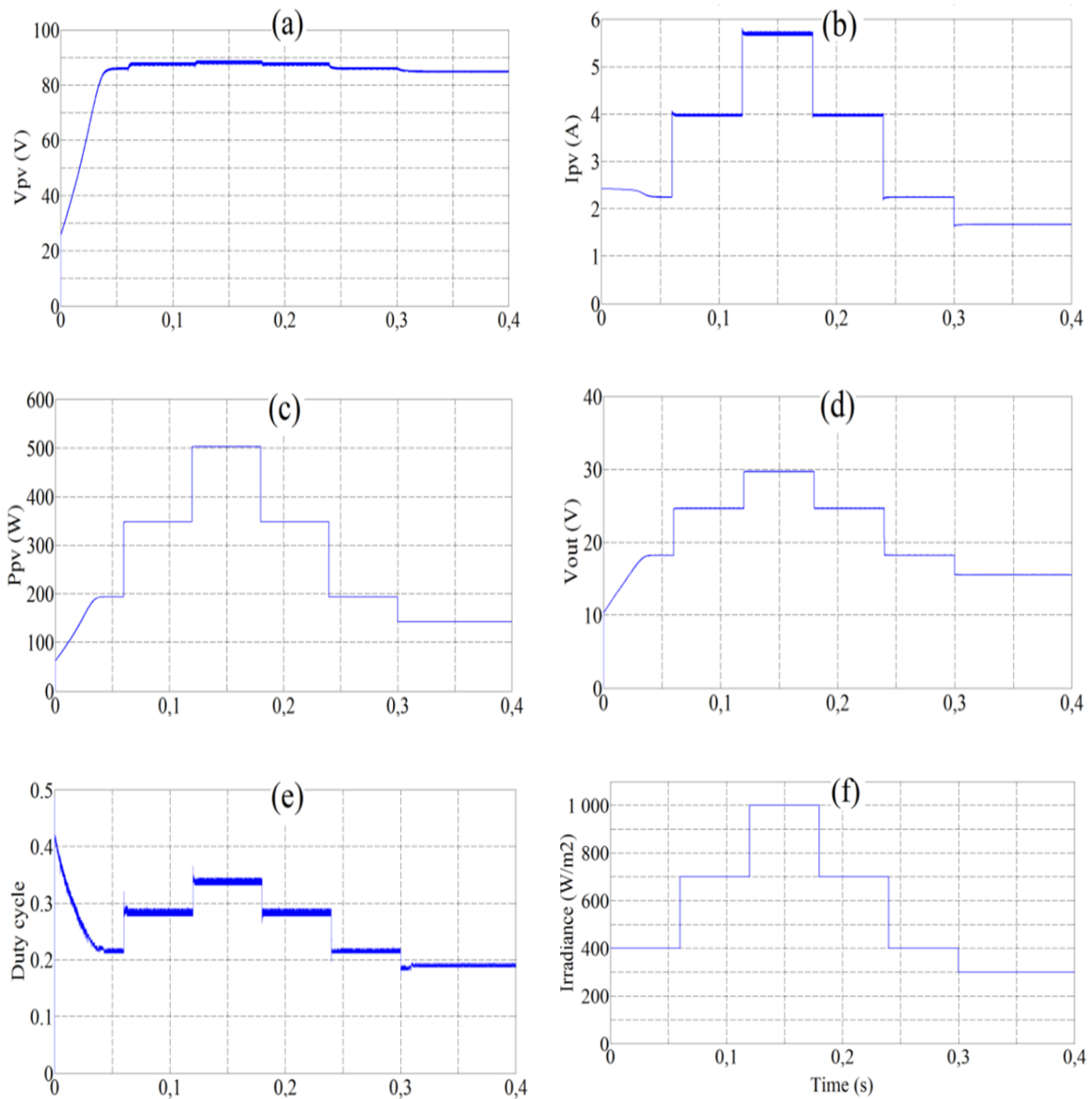

Figure 8. (a-c) Respectively voltage, current and power of PV array, (d) load voltage (e) duty cycle of buck control and (f) irradiance profil using SMC P\&O MPPT algorithm 

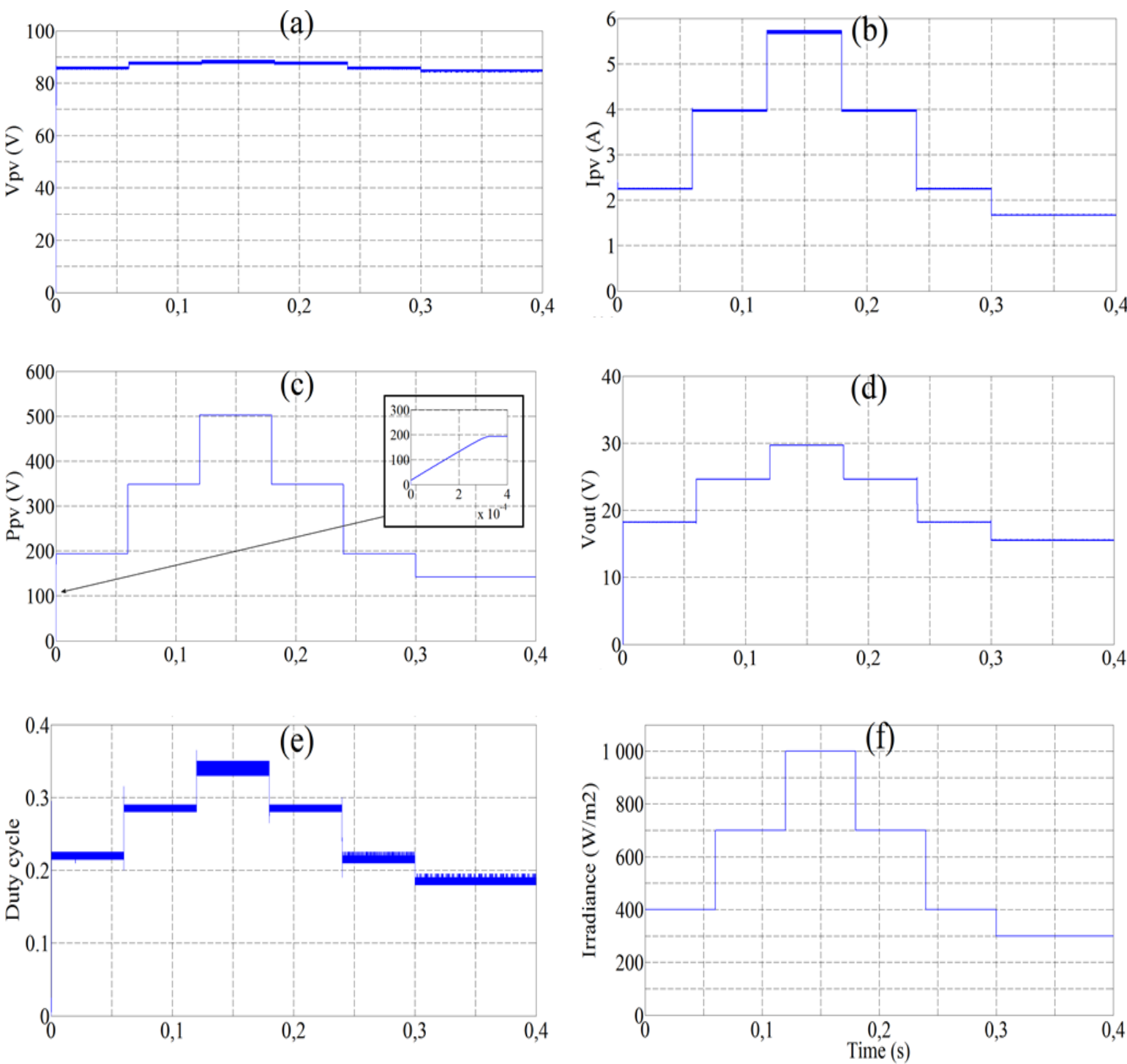

Figure 9. (a-c) Respectively voltage, current and power of PV array, (d) Load voltage (e) duty cycle of buck control and (f) irradiance profil using SMC incremental conductance MPPT algorithm

\section{CONCLUSION}

In this paper, an improved maximum power point tracking (MPPT) controllers of a PV system in various climatic conditions is presented. The control based upon the sliding mode approach for PV system is synthesized. Using this fast and robust control system, suitable MPPT performances are obtained. Indeed, the design of MPPT control with sliding mode for photovoltaic system based a static buck converter represent one of the most effective ways to optimize PV systems with high performances. The key novelty of the control algorithm presented lies in the way dynamic of different methods to design sliding mode control with MPPT. A comparison between a sliding mode controller MPPT, a controller with incremental conductance algorithm and a one with perturb and observe algorithm is ended. The three controllers are efficient and robust. Rapidity to reach the maximum power point is the quality of the two cited above compared to the Perturb and Observe algorithm.

\section{REFERENCES}

[1] N. Hamrouni, M. Jraidi, and A. Chérif, "Solar radiation and ambient temperature effects on the performances of PV pumping System," Journal of Renewable Energies, vol. 11, no. 1, pp. 95-106, 2008.

[2] S. Premrudeepreechacharn and N. Patanapirom, "Solar-array modelling and maximum power point tracking using neural networks," in 2003 IEEE Bologna Power Tech Conference Proceedings, Bologna, Italy, vol. 2, pp. 5, 2003. 
[3] J. Sai Kumar and Tikeshwar Gajpal, "A Multi Input DC-DC Converter for Renewable Energy Applications," International Research Journal of Engineering and Technology (IRJET), vol. 3, no. 6, pp. 380-384, June 2016.

[4] A. Daoud and A. Midoun, "Simulation and experimental study of maximum power point tracker based on a DC/DC buck converter," International Review of Electrical Engineering, vol. 5, no. 2, part A, pp. 514-520, April 2010.

[5] G. Petrone, G. Spagnuolo, and M. Vitelli, "Distributed Maximum Power Point Tracking: Challenges and Commercial Solutions," Automatika, vol. 53, no. 2, pp. 128-141, 2012.

[6] A. R. Reisi, M. H. Moradi, and H. Showkati, "Combined photovoltaic and unified power quality controller to improve power quality," Solar Energy, vol. 88, pp. 154-162, February 2013.

[7] M. A. G. de Brito, L. P. Sampaio, L. G. Junior, and C. A. Canesin, "Evaluation of MPPT techniques for photovoltaic applications," in IEEE International Symposium on Industrial Electronics, Gdansk, Poland, pp. 1039-1044, 2011.

[8] R. F. Coelho, W. M. dos Santos, and D. C. Martins, "Influence of power converters on PV maximum power point tracking efficiency," in 10th IEEE/IAS International Conference on Industry Applications (INDUSCON), Fortaleza, Brazil, pp. 1-8, 2012.

[9] M.G. Villalva, J.R. Gazoli, and E.R. Filho, "Analysis and simulation of the P\&O MPPT algorithm using a linearized PV array model," in Power Electronics Conference, 2009.Brazilian, pp. 189-195. 2009.

[10] A. Elgendy, B. Zahawi, and D.J. Atkinson, "Evaluation of Perturbe and Observe MPPT Algorithm Implementation Techniques," in 6th IET International Conference on Power Electronics, Machines and Drives (PEMD 2012), Bristol, UK, pp. 1-6, 2012.

[11] I. Mustafa and K. Naz, "Modified Perturb and Observe MPPT Algorithm for PV System," International Journal of Electrical Engineering \& Emerging Technology(IJEEET), vol. 1, no. 1, pp. 30-36, December 2018.

[12] J. H. Lee, H. Bae, and B. H. Cho, "Advanced Incremental Conductance MPPT Algorithm with a Variable Step Size," in 12th International Power Electronics and Motion Control Conference EPEPEMC, Portoroz, Slovénie, pp. 603-607, 2006.

[13] M. M. Shebani, T. Iqbal, and J. E. Quaicoe, "Comparing bisection numerical algorithm with fractional short circuit current and open circuit voltage methods for MPPT photovoltaic systems," in IEEE Electrical Power and Energy Conference (EPEC), Ottawa, ON, Canada, pp. 1-5, octobre 2016.

[14] A. R. Reisi, M. H. Moradi, and S. Jamasb, "Classification and comparison of maximum power point tracking techniques for photovoltaic system: A review," Renewable and Sustainable Energy Reviews, vol. 19, pp. 433-443, March 2013.

[15] P. Vipin, V. Beena, and M. Jarayaju, "Fuzzy logic based maximum powerpoint tracker for a photovoltaic system," in International Conference on Power, Signals, Controls and Computation (EPSCICON), pp. 1-6, 2012.

[16] A. Tariq and M. S. Jami Asghar, "Development of an Analog Maximum Power Point Tracker for Photovoltaic Panel," International IEEE Annual Conference on Power and Electronics and Drives Systems, vol. 1, pp. 251-255, January 2006.

[17] Theodoros L. Kottas, Yiannis S. Boutalis, and Athanassios D. Karlis, "New Maximum Power Point Tracker for PV Arrays Using Fuzzy Controller in Close Cooperation With Fuzzy Cognitive Networks," IEEE Transactions on Energy Conversion, vol. 21, no. 3, September 2006.

[18] B. Sefriti, M. Ameziane, I. Boumhidi, and K. Slaoui, "Robust adaptive sliding mode control of a photovoltaic water pumping system using fuzzy wavelet network and PSO algorithm," International Journal of Power and Energy Conversion (IJPEC), vol. 6, no. 3, July 2015.

[19] A. G. Al-Gizi and S. J. Al-Chlaihawi, "Study of FLC based MPPT in comparison with P\&O and InC for PV systems," in International Symposium on Fundamentals of Electrical Engineering (ISFEE), Bucharest, Romania, pp. 1-6, 2016.

[20] A. G. Al-Gizi, A. Craciunescu, and S. J. Al-Chlaihawi, "The use of ANN to supervise the PV MPPT based on FLC," in 10th International Symposium on Advanced Topics in Electrical Engineering (ATEE), Bucharest, Romania, pp. 703-708, 2017.

[21] N. Khaldi, H. Mahmoudi, M. ZAZI, and Y. BARRADI, "Implementation of a MPPT Neural Controller for Photovoltaic Systems on FPGA Circuit," WSEAS TRANSACTIONS on POWER SYSTEMS, vol. 9, pp. 471-478, 2014.

[22] Naghmash et al., "Backstepping based non-linear control for maximum power point tracking in photovoltaic system," Solar Energy, vol. 159, no. 1, pp. 134-141, January 2018.

[23] E. Mamarelis, G. Petrone, and G. Spagnuolo, "Design of a Sliding-Mode-Controlled SEPIC for PV MPPT Applications," IEEE Transactions on Industrial Electronics, vol. 61, no. 7, pp. 3387-3398, July 2014.

[24] H. Abouobaida, M. Khayat, and M. Cherkaoui, "Combination of RCC MPPT and backstepping controler to design a standard continuous source (12V-24V) supplied by a PV panels," H. Abouobaida, M. Khayat, and M. Cherkaoui, "Combination of RCC MPPT and backstepping controler to desig" Journal of Electrical Engineering, vol. 14, no. 3, pp. 364-371, 2014.

[25] J. El Khazane and E. Tissir, "Achievement of MPPT by finite time convergence sliding mode control for photovoltaic pumping system," Solar energy, vol. 166, pp. 13-20, May 2018.

[26] A. Taouni, A. Abbou, M. Akherraz, A. Ouchatti, and R. Majdoul, "MPPT design for photovoltaic system using backstepping control with boost converter," in International Renewable and Sustainable Energy Conference (IRSEC), Marrakech, Morocco, pp. 469-475, 2016.

[27] Y. Chaibi, M. Salhi, and A. El-jouni, "Sliding Mode Controllers for Standalone PV Systems: Modeling and Approach of Control," International Journal of Photoenergy, vol. 2019, pp. 1-12, Article ID 5092078, 2019. 
[28] M. Arsalan, R. Iftikhar,.H. Ammar I. Ahmad, and A. Javeria K. Sabahat, "MPPT for photovoltaic system using nonlinear backstepping controller with integral action," Solar energy, vol. 170, pp. 192-200, August 2018.

[29] C. C. Chu and C. L. Chen, "Robust maximum power point tracking method for photovoltaic cells: A sliding mode control approach," Solar Energy, vol. 83, no. 8, pp. 1370-1378, August 2009.

[30] M. Guisser, E. Abdelmounim, M. Aboulfatah, and A. EL-Jouni, "Nonlinear Observer-Based Control for Grid Connected Photovoltaic System," Journal of Electrical and Electronics Engineering, vol. 9, no. 5, pp. 40-52, Sep-Oct 2014.

[31] A. Touati, A. Abouloifa, E. Abdelmounim, and M. Aboulfatah, "Observation and control of a single-phase DC-AC converter with sliding mode," in 4th IEEE Conference on Multimedia Computing and Systems Marrakesh, Morocco, April 2014, pp.1539- 1544., Marrakesh, Morocco, April, pp. 1539-1544, 2014.

[32] Ravi Nath Tripathi, Alka Singh and Tsuyoshi Hanamoto, "Design and control of LCL filter interfaced grid connected solar photovoltaic (SPV) system using power balance theory," Electrical Power and Energy Systems, Vol. 69, pp. 264-272, 2015.

[33] S. Sheik Mohammed, D. Devaraj and T. P. Imthias Ahamed, 2016, "Maximum power point tracking system for stand alone solar PV power system using Adaptive Neuro-Fuzzy Inference System," Biennial International Conference on Power and Energy Systems: Towards Sustainable Energy (PESTSE), pp. 1-4, 2016.

[34] A. Taouni, M. Akherraz, A. Abbou, A. Ouchatti and K. Majdoub, "Hybrid Resolution of Solar Cells Model Parameters Using Analytical and Numerical Method," IREMOS, vol. 8, no. 5, p. 591, 2015.

\section{BIOGRAPHIES OF AUTHORS}
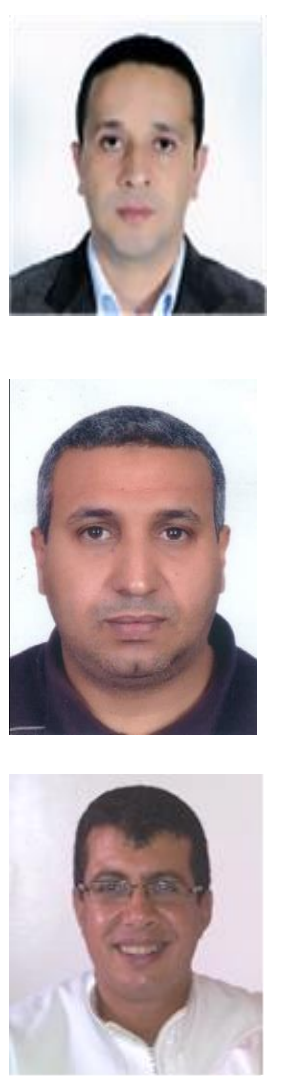

Abderrahim Taouni was born in Morocco in 1974. He received the Engineer degree in electrical Engineering from High Institute of Technical Education (ENSET) of Mohammedia in 1997. Received the Aggregation in Electrical Engineering from the Ecole Normal Superior of Technical Education (ENSET), Rabat, in 2008. He received the Master degree in ATSII (Automatic, Signal Processing and Industrial Computing) from Faculty of Science and Technology Hassan I university SETTAT, Morocco in 2011 Currently he is Research Professor Laboratory of Electrical Systems \& Control Engineering (ESCE) - Aïn Chock Science faculty- Hassan II University Casablanca, Morocco. His research interests include control strategies for AC machine Drives, renewable energy and batteries.

\begin{abstract}
Abdelwahed Touati was born in Casablanca, Morocco, in 1970. He received the Engineer degree in electrical Engineering from High Institute of Technical Education (ENSET) of Mohammedia in 1993. In 1999, he successfully passed the external aggregation contest. In 2012 he received the MASTER ATSII (Automatic Signal Processing and Industrial Computing) from HASSAN 1 University - FST of SETTAT Morocco. Currently he is Research Professor Laboratory of Structural Engineering, Intelligent Systems \& Electrical Energy ENSAM, Department of Electrical Engineering - Hassan II University Casablanca, Morocco. His research interests include control strategies for AC machine Drives, renewable energy and Power Quality.
\end{abstract}

Radouane Majdoul was born in Meknes, Morocco, in 1969. He received the Engineer degree in electrical Engineering from High Institute of Technical Education (ENSET) of Rabat in 1991. In 1997, he successfully passed the external aggregation contest. In 2012 he received the MASTER ATSII (Automatic Signal Processing and Industrial Computing) from HASSAN 1ST University - FST of Settat Morocco. Currently he is Research Professor Laboratory of Structural Engineering, Intelligent Systems \& Electrical Energy ENSAM, Department of Electrical Engineering - Hassan II University Casablanca, Morocco. His research interests include control strategies for AC machine Drives, renewable energy and Power Quality. 